\section{Platelet Indices Evaluation in Patients With Fibromyalgia Syndrome: Methodological Drawbacks}

\author{
Ercan VAROL \\ Department of Cardiology, Medical Faculty of Süleyman \\ Demirel University, Isparta, Turkey
}

I read the article published by Ünübol et al. ${ }^{1}$ with great interest. The authors evaluated mean platelet volume (MPV) and serum lipid profiles in patients with fibromyalgia syndrome (FMS). Mean platelet volume values were higher in patients with FMS than in controls. Although this is a well-written study, it has some methodological drawbacks.

The researchers screened complete blood counts and biochemical analysis of FMS patients. However, they did not specify the MPV measurement technique in detail. Accurate measurements of platelet count and volume are important for diagnostic, therapeutic, and research purposes. The choice of anticoagulant [ethylenediaminetetraacetic acid (EDTA) or citrate], time interval of measurement, and temperature at which MPV is analyzed are important factors in MPV measurement. The time-dependent swelling of platelets in samples anticoagulated with EDTA can result in an artifactual increase in MPV, causing misinterpretation of prothrombotic changes. ${ }^{2}$ In actual daily practice, MPV measurements are performed at room temperature, and temperature factor can be negligible. However, the choice of anticoagulant and time interval of MPV measurement are important issues. Mean platelet volume increases over time in EDTA-anticoagulated samples, and this increase was shown to be proportional with the time delay between sample collection and laboratory analysis. With impedance counting, the MPV increases over time as platelets swell in EDTA, with reported increases of $7.9 \%$ within 30 minutes and an overall increase of $13.4 \%$ over 24 hours, although the majority of this increase occurs within the first six hours. ${ }^{2}$ Dastjerdi et $\mathrm{al}^{3}$ recommended measuring MPV within one hour regardless of anticoagulant. Lancé et al. ${ }^{2}$ reported that an optimal stability was detected in potassium (K2) EDTA after 120 minutes. It is widely accepted that platelet swelling in test tubes can be minimized by rapid processing of samples, i.e. within less than 1 hour. ${ }^{3}$ For a reliable MPV measurement, the potential influence of EDTA anticoagulant on the MPV must be carefully controlled by standardizing the time delay between sampling and analysis. Moreover, the control and standardization of MPV measurement is more challenging in retrospective studies. It would have been beneficial if the authors had indicated these factors.

Mean platelet volume is universally available with routine blood counts by automated hemograms. Compared to smaller platelets, larger platelets have more granules, aggregate more rapidly with collagen, have higher thromboxane A2 level, and express more glycoprotein Ib and IIb/IIIa receptors. ${ }^{2,4}$ On the other hand, MPV can be affected by many risk factors for cardiovascular disease. Thus, all confounding factors should be taken into account, and detailed standardized methods must be used in MPV measurement.

\section{Declaration of conflicting interests}

The author declared no conflicts of interest with respect to the authorship and/or publication of this article.

Received: July 04, 2014 Accepted: July 04, 2014

Correspondence: Ercan Varol, M.D. Süleyman Demirel Üniversitesi Tıp Fakültesi Kardiyoloji Anabilim Dalı, 32260 Çünür, Isparta, Turkey.

Tel: +90 246 - 2119346 e-mail: drercanvarol@yahoo.com

๑)2014 Turkish League Against Rheumatism. All rights reserved. 


\section{Funding}

The author received no financial support for the research and/or authorship of this article.

\section{REFERENCES}

1 Unubol AI, Bozbağ GT, Unubol M, Gurer G. An evaluation of mean platelet volume and serum lipid profile in patients with fibromyalgia syndrome. Arch Rheumatol 2013;28:251-5.

2. Lancé MD, Sloep M, Henskens YM, Marcus MA. Mean platelet volume as a diagnostic marker for cardiovascular disease: drawbacks of preanalytical conditions and measuring techniques. Clin Appl Thromb Hemost 2012;18:561-8.

3. Dastjerdi MS, Emami T, Najafian A, Amini M. Mean platelet volume measurement, EDTA or citrate? Hematology 2006;11:317-9.

4. Gasparyan AY, Ayvazyan L, Mikhailidis DP, Kitas GD. Mean platelet volume: a link between thrombosis and inflammation? Curr Pharm Des 2011;17:47-58.

\section{Author's Reply}

We read with interest the letter with the title 'Platelet Indices Evaluation in Patients with Fibromyalgia Syndrome; Methodological Drawbacks' in which the author emphasized the importance of mean platelet volume (MPV) measurement technique.

There are so many studies which MPV values were recorded retrospectively in the literature..$^{1-5}$ In the medical centers where this study took place, blood samples collected for whole blood count are analyzed within one hour. Although this is a retrospective study, we may say that measurement of MPV values were analyzed within one hour after blood sampling in all patients. Therefore, this technical condition was ensured in this retrospective study.

\section{REFERENCES}

1. Ju HY, Kim JK, Hur SM, Woo SA, Park KA, Park MY, et al. Could mean platelet volume be a promising biomarker of progression of chronic kidney disease? Platelets. 2014 Mar 28. [Epub ahead of print]

2. Aypak C, Türedi O, Bircan MA, Yüce A. Could mean platelet volume among complete blood count parameters be a surrogate marker of metabolic syndrome in prepubertal children? Platelets 2014;25:393-8.

3. Tekin G, Tekin YK, Sivri N, Yetkin E. Mean platelet volume in patients with nonvalvular atrial fibrillation. Blood Coagul Fibrinolysis 2013;24:537-9.

4. Özlü MF, Öztürk S, Ayhan SS, Tosun M, Alçelik $\mathrm{A}$, Erdem A, et al. Predictive value of mean platelet volume in young patients with non-STsegment elevation acute coronary syndromes: a retrospective observational study. Anadolu Kardiyol Derg 2013;13:57-61.

5. Slavka G, Perkmann T, Haslacher H, Greisenegger S, Marsik C, Wagner OF, et al. Mean platelet volume may represent a predictive parameter for overall vascular mortality and ischemic heart disease. Arterioscler Thromb Vasc Biol 2011;31:1215-8.

Correspondence: Ayșe İyiyapıcı Ünübol, M.D. Söke Devlet Hastanesi Fiziksel Tip ve Rehabilitasyon Kliniği, 09200 Söke, Aydın, Turkey.

Tel: +90 256 - 5182361 e-mail: aiyiyapici@yahoo.com 